\title{
EDUKASI PEMBACAAN LABEL DAN KODE KEMASAN PANGAN BAGI ANGGOTA PRISTA KECAMATAN LIMO, DEPOK
}

\author{
Erna Megawati \\ Pendidikan Bahasa Indonesia, Universitas Indraprasta PGRI \\ Megawatie45@yahoo.com
}

\begin{abstract}
Abstrak
Kegiatan pengabdian kepada masyarakat ini dilakukan dalam rangka memberikan edukasi dalam pembacaan label pangan dan kode kemasan bagi anggota IKRA RW 03 Kecamatan Limo, Kota Depok. Melalui kegiatan ini diharapkan bisa memberikan pemahaman secara teoretis kepada para anggota IKRA dalam membaca label pangan dan kode kemasan. Diharapkan dengan kegiatan ini, para anggota IKRA akan menyebarkan informasi tersebut kepada masyarakat sekitar sehingga masyarakat dalam mengerti isi kemasan dan keamanan kemasan pangan yang dibelinya.
\end{abstract}

Kata Kunci: Label Pangan, Kode Kemasan dan IKRA

\begin{abstract}
The objective of this activity is to give education in reading and comprehend food labelling and wrapping code based on SPI for IKRA's members in RW. 03, kecamatan Limo, Depok City. Through this activity, the members of IKRA are directed to understand how to read food labelling and wrapping code. After this activity, the knowledge is hoped to be spread to the society so that they are able to understand the content and the safety of things they bought.
\end{abstract}

Key words: Food labelling, wrapping code and IKRA

\section{PENDAHULUAN}

Manusia dalam kehidupannya berinteraksi dengan masyarakat membentuk kumpulan atau komunitas. Komunitas adalah kelompok social yang di dalamnya terdiri dari individu-individu yang saling berbagi lingkungan serta memiliki ketertarikan dan habibat yang sama (Tambunan, 2017). Dengan demikian, komunitas terdiri dari beberapa individu yang mendiami wilayah yang sama dan berbadi minat serta ketertarikan yang sama. Dari perspektif sosiologi, kata komunitas diambil dari kata community yang bahasa Latinnya adalah Munus dengan makna the gift (memberi), cum dan together (kebersamaan) (Ngarbingan, 2016). Komunitas dalam pandangan ini adalah sekumpulan manusia yang berbagi dan saling memberikan dukungan yang disebabkan adanya interaksi social secara terus menerus. Dengan demikian, dari pandangan sosiologis suatu komunitas mempunyai social relationship yang kuat sehingga mereka merasa diikat oleh kepentingan yang sama. 
Berdasarkan pengertian tersebut, maka para remaja yang tinggal di wilayah RW 03 kecamatan Limo, Depok, juga dapat digolongkan sebagai satu perkumpulan dengan kesamaan pada wilayah dan tujuan. IKRA merupakan wadah bagi para remaja RW 03, kecamatan Limo, Depok, untuk berkumpul dan belajar berorganisasi. Para remaja ini memegang peran penting karena masa depan ada di tangan generasi muda. Segala perubahan, perbaikan dilakukan oleh generasi muda.

Fenomena menarik yang terjadi saat ini adalah kurangnya pemahaman masyarakat, termasuk para anggota IKRA mengenai komposisi makanan/ minuman dalam kemasan. Hal tersebut mendorong banyak warga/ masyarakat tidak tahu manfaat atau bahkan kerugian dari mengkonsumsi suatu produk dalam kemasan.

Sebut saja kejadian yang terjadi di masyarakat saat ini yaitu fenomena Susu Kental Manis (SKM). Kepala BPOM Penny K. Lukito, seperti dilansir dalam tribunews (http://tribunews.com), senin, 9 Juli 2018, mengutarakan bahaawa kandungan susu kental manis adalah susu yang dikentalkan sebelum ditambahkan gula yang menjadikannya manis. Air (susu)-nya dikeluarkan, di-evaporate, di-condense, dikentalkan kemudian ditambah gula. Jadi, lemaknya itu terkonsentrasi terus ditambah gula,. Lebih lanjut dijelaskan bahwa kandungan lemak yang harus dipertahankan dalam susu cair sebesar 8 $\%$ dan protein kurang dari $6.5 \%$. Kesalahan persepsi yang terjadi di masyarakat adalah adanya anggapan bahwa SKM adalah susu., padahal berdasar Surat edaran BPOM kepada para produsen, importir, distributor produk susu kental, dan analognya. Surat edaran itu bernomor HK.06.5.51.511.05.18.2000 tahun 2018 mengenai Label dan Iklan pada Produk Susu Kental dan Analognya (Kategori Pangan 01.3)

Dengan demikian, informasi nilai gizi maupun komposisi dari suatu produk merupakan hal yang penting untuk dipahami. Label makanan merupakan bentuk tanggung jawab produsen kepada konsumen. Pada label makanan dimuat informasi mengenai kandungan dari produk tersebut. Namun sayang, belum banyak masyarakat yang memerhatikan label pangan ketika membeli atau menggunakan suatu produk. Hal ini juga terjadi di wilayah RW 03, kecamatan Limo, Depok.

Anggota IKRA belum memiliki pemahaman yang mumpuni tentang label pangan sehingga belum adanya satu langkah sosialisasi untuk mengajak warga sekitar untuk membaca label pangan sebelum membeli/ menggunakan satu produk. Masalah lain juga yang muncul pada mitra adalah belum adanya pemahaman mengenai keamanan kemasan pangan. Panganan yang ada dipasaran terbuat dari berbagai bahan, namun tidak semua kemasan bisa dipakai berulang-ulang sesudah isi produk habis. Ketidakpahaman mengenai penggunaan kemasan pangan menyebabkan masyarakat tidak memahami bahaya yang mengintai ketika salah dalam penggunaan.

Mengingat pentingnya pengetahuan mengenai arti label pangan dan pemahaman mengenai kemasan yang memenuhi syarat mendorong tim pengabdian masyarakat kami untuk melaksanakan kegiatan berupa edukasi pembacaan label pangan dan penggunaan kemasan pangan bagi anggota PRISTA. Kegiatan ibM ini bertujuan untuk memberikan pelatihan tentang cara membaca label pangan dan kode kemasan pangan bagi anggota IKRA sehingga mereka dapat memberikan informasi tersebut kepada seluruh warga di kelurahan terebut..

Berdasarkan uraian di atas, tim pelaksana tertarik untuk melakukan kegiatan Iptek bagi Masyarakat pada anggota IKRA dengan judul Edukasi Pembacaan Label dan Kode Kemasan Pangan bagi Anggota IKRA (Ikatan Remaja RW 03) Kecamatan Limo, Depok 


\section{METODE PELAKSANAAN}

Minimnya pengetahuan anggota IKRA terhadap keterampilan membaca label dan kode kemasan pangan maka edukasi berkenaan dengan hal tersebut dianggap penting. Untuk itu, solusi yang ditawarkan, yaitu memberikan pemahaman dan pelatihan tentang cara membaca label dank ode kemasan pangan.

Kegiatan ini menggunakan konsep pemahaman membaca label dan kode kemasan pangan. Kami menggunakan sekertariat IKRA kelurahan Gedong sebagai tempat presentasi dan evaluasi pemahaman pembacaan label dan kode pangan. Metode yang digunakan adalah metode ceramah dan diskusi mengenai hal-hal yang berkaitan dengan surat menyurat. Waktu Pelaksanaan ABDIMAS ini akan dimulai pada bulan September 2018 hingga Oktober 2018. Pelaksanan edukasi tersebut adalah tanggal 21 September 2018, pukul 20.00 .

Alat-Alat yang Digunakan dalam edukasi ini adalah kerja sama antara tim abdimas dan mitra. Mitra menyediakan ruangan, pengeras suara dan proyektor, sedangkan tim abdimas menyiapkan komputer jinjing, lembaran materi, alat tulis dan buku catatan penunjang kegiatan.

Agenda pelaksanaan kegiatan ABDIMAS ini diselenggarakan dengan berbagai tahapan seperti berikut: tersebut akan dibagi menjadi beberapa tahapan. Observasi langsung. Observasi langsung yakni tim pengabdi melakukan interview dengan anggota IKRA mengenai pemahaman tentang label dan kode kemasan pangan sebagai data. Observasi berguna untuk mengetahui kondisi pemahaman mitra terhadap label dan kode kemasan pangan. Observasi sangat penting untuk mewujudkan kesuksesan kegiatan pengabdian masyarakat itu sendiri. Pelatihan, yaitu tim pelaksana melatih secara langsung mengenai pembacaan label dan kode kemasan pangan. Evaluasi, yaitu melakukan proses evaluasi terhadap pemahaman mitra terhadap label dan kode pangan.

\section{HASIL DAN PEMBAHASAN}

Realisasi Pelaksanaan Kegiatan yang dijadwalkan tanggal 21 September 2018, pada awal kegiatan, ketua rombongan abdimas Unindra yang terdiri dari Erna Megawati, Azhari Ikhwati diterima oleh perwakilan anggota IKRA. Pada sambutannya, beliau mengucapkan terima kasih atas kesedian tim abdimas Unindra yang hendak melalukan edukasi pembacaan label pangan dan kode kemasan pangan sekaligus mengimbau para peserta dapat mengikuti kegiatan abdimas dengan baik untuk menambah wawasan keilmuan.

Dengan diadakannya kegiatan ini, diharapkan dapat memberi pemahaman kepada anggota IKRA agar lebih memerhatikan kode pangan dan kemasan agar tahu komposisi barang yang dibeli dan keamanan kemasannya. Kegiatan selanjutnya adalah tahap edukasi melalui pemaparan teoretis. Tim abdimas melakukan diskusi intern yang bertujuan mendapatkan hasil yang maksimal dalam kegiatan ini.

1. Membaca

Harras (Harras, 2014) mengemukakan bahwa membca merupakan suatu prasayart mutlak dalam memeroleh kemajuan. Melalui membaca, seseorang dapat memeroleh pengetahuan yang dapat mendorongnya menjadi lebih maju. Dengan demikian, membaca bukanlah proses tunggal tapi merupakan kombinasi dari berbagai 
proses yang berakumulasi pada satu proses yaitu membaca. Jadi, membaca bukanlah satu kegiatan pasif melainkan satu proses aktif yang dilakukan secara sadar, mempunyai tujuan, yang pemahaman dan pemaknaannya ditentukan oleh pengalaman yang dimiliki oleh pembaca, dalam proses membaca terjadi kolaborasi antara pengetahuan lama pembaca dan baru yang mengantar pada pemahaman.

Prof. Leo Fay dalam (Harras, 2014) menyatakan bahwa, 'To read is to possess a power for transcending whatever physical human can muster'. Dalam pandangannya membaca dapat mengantar seseorang memeroleh kekuatan untuk melampaui semua aktifitas fisik yang dapat dilakukan manusia. Demikian pentingnya peran membaca dalam kehidupan manusia yang tanpanya seserorang atau kelompok manapuna akan sulit mengangkat kualitas dirinya ataupun kelompoknya.

Anderson dalam (Harras, 2014) menyatakan, "reading is a recording and decoding process." Membaca adalah suatu proses merekam dan decoding. Hal ini bermakna bahwa melalui membaca maka seseorang sama dengan merekam informasi yang diperolehnya melalui bacaan tersebut sekaligus melakukan proses decoding dalam rangka mengungkapkan pesan atau maksud yang disampaikan oleh penulis di dalam bahasa tulis melalui fitur-fitur bahasa.

Membaca juga merupakan salah satu metode yang digunakan dalam proses pembelajaran. Metode Glenn Doman (Ahmadi, 2010) adalah salah satu metode pembelajaran yang menggunakan membaca sebagai metode utamanya. Anak-anak menggunakan flash card dalam pembelajaran sehingga timbul rasa percaya diri, imaginasi serta kesenangan dalam belajar. Membaca diyakini sebagai kunci dalam memeroleh pengetahuan untuk mencapai kemajuan dan kesuksesan.

Ruddell dalam Morrow (Aulina, 2012) memberikan definisi bahwa membaca merupakan penggunaan berbahasa dalam rangka menguraikan bentuk tulisan maupun symbol untuk memeroleh pemahaman. Definisi ini sejalan dengan yang diajukan oleh Tarigan (Hastuti, 2012) bahwa membaca merupakan proses dimana pembaca memeroleh pesan yang hendak disampaikan penulis melalui fitur kata-kata atau bahasa tulis. Hal ini berarti bahwa membaca adalah kegiatan terkait kebahasaan yang bertujuan mengungkapkan serta memeroleh pengetahuan yang ada dalam bahasa.

Razak (Amna, Azwandi, \& Yunus, 2013) menjelaskan bahawa dalam membaca pemahaman maka pembaca sanggup menyebutkan kembali isi bacaan baik argumentasi, ekspositori maupun bacaan deskripsi mengenai satu topik tertentu. Dengan demikian, tahapan membaca bukan hanya sampai pada mengetahui dan memahami isi bacaan tapi mencapai tahapan sang pembaca mampu menyampaikan kembali isi bacaan tersebut.

Sungguh disayangkan minat membaca di Indonesia berdasarkan data UNESCO (Permatasari, 2015)hanya menunjukkan indeks 0,001 yang artinya pada setiap 1000 orang hanya satu orang yang memiliki minat membaca. Tingkat literasi kita hanyalah 64 dari 65 negara yang disurvei. Dengan demikian, membaca belum menjadi kebiasaan di Indonesia, demikian pula di tataran komunitas yang ada di masyarakat.

2. Label dan Kode Kemasan Pangan

Label pangan adalah setiap keterangan mengenai pangan yang berbentuk gambar, tulisan, kombinasi keduanya, atau bentuk lain yang disertakan pada pangan, dimasukkan ke dalam, ditempelkan pada, atau merupakan bagian kemasan pangan. Label dan iklan pangan termasuk dalam lingkup pengaturan penyelenggaraan pangan yang diatur dalam Undang-Undang Republik Indonesi nomor 18 tahun 2012 tentang 
pangan (Indonesia, 2012). Hal tersebut diatur dalam pasal 67 yang menyebutkan bahwa keamanan pangan diselenggarakan untuk menjaga pangan tetap aman, higienis, bermutu, dan tidak bertentangan dengan agama, keyakinan, dan budaya masyarakat. Dengan demikian, label pangan digunakan dalam rangka penjaminan pangan dengan jalan memberikan informasi nilai kandungan pangan yang akan dikonsumsi.

Brandt dan LeGault dalam (Syahlani, 2006) menyebutkan bahwa penjulan produk yang dilakukan di Amerika Serikat berada dalam pengawasan badan makanan dan obat-obatan (Food and Drug Administration) yang mewajibkan penggunaan label pangan 20 produk pertanian dan perikanan serta memberikan ajuran agar produk pertanian dan periklanan lain untuk membantu konsumen dalam membeli sesuai kebutuhan. Dengan demikian jelas bahwa persoalan label pangan sebagai satu usaha pengemanan konsumsi bukan saja isu nasional tetapi juga berskala internasional.

Tujuan label pangan adalah agar informasi mengenai pangan yang disampaikan kepada masyarakat adalah benar dan tidak menyesatkan dan terciptanya perdagangan pangan yang jujur dan bertanggungjawab. Fungsi pelabelan adalah sebagai identifikasi produk, membantu penjualan produk dan pemenuhan peraturan perundang-undangan.

Kode pada dikeluarkan oleh The Society of Plastic Industry dan sudah diadopsi oleh badan standardisasi internasional seperti ISO (International Organization of Standardization). Kode ini umumnya tertera di bagian bawah kemasan dan berbentuk segitiga dengan angka di dalamnya dan nama jenis plastik di bawah segitiga.

Peraturan mengenai perlindungan konsumen terhadap penggunaan kemasan plastic diatur dalam pasal UUPK (Undang-Undang Perlindungan Konsumen) antara lain pasal 4a dan c, Pasal 7b dan d, dan Pasal 8 ayat 1a dan ayat 3 (Purwanta, 2012). Pasal \$a UUPK memberikan hak keamanan bagi konsumen dalam mengkonsumsi barang dan/atau jasa. Dengan demikian para produsen harus bisa menjamin semua bahan-bahan yang diperdagangkan aman mulai dari bahannya sampai dengan kemasannya. Pasal 4c menjelaskan hak konsumen untuk mendapatkan informasi yang jelas, benar, dan jujur mengenai kondisi dan adanya jaminan terhadap barang atau jasa. Setiap produsen harus mencantumkan kode kemasan dengan symbol dan kode segitiga yang dikeluarkan oleh The Society of Plastic Industry sehingga konsumen tahu bahwa kemasan yang digunakan aman atau tidak. Pasal $7 \mathrm{~b}$ mewajibkan para pelaku usaha untuk memberikan infomasi secara benar, jujur dan jelas mengenai barang dan/atau jasa. Dengan demikian para konsumen dapat menentukan pilihan dengan tepat. Pasal 7d mewajibkan pelku usaha untuk menjamin mutu bara dan/atau jasa yang dipasarkan berdasarkan ketentuan standar yang berlaku. Pasal 8 ayat (1) melarang pelaku usaha untuk memroduksi dan/atau memperdagangkan barang dan/atau jasa yang tidak memenuhi standar persyaratan berdasarkan ketentuan perundang-undangan. Dengan demikian, hak konsumen untuk mendapatkan barang dan/atau jasa yang memenuhi standar. Pasal 8 ayat (3) melarang pelaku usaha untuk memperdagangkan sediaan farmasi dan pangan dalam keadaan rusak, cacat atau bekas dan tercemar, dengan atau tanpa memberikan informasi secara lengkap dan benar. Dengan demikian, apapun alasannya para pelaku usaha tidak diperkenankan untuk memperdagangkan barang dalam kondisi tidak aman.

Demikian pentingnya persoalan label pangan dan kode kemasan pangan inilah yang emndorong tim pelaksana untuk melakukan kegiatan pengabdian kepada masyarakat berupa satu dorongan bagi anggota IKRA untuk mulai membiasakan 
untuk membaca label pangan dan kode kemasan. Pada saat melakukan pelatihan, tim abdimas menyampaikan materi mengenai hakikat membaca, label pangan dan kode kemasan.

Selanjutnya, diadakan sesi tanya jawab, diskusi dan konsultasi untuk menggali dan memaparkan hal-hal yang belum dikuasai dan belum dipahami dari pembacaan label pangan dan kode kemasan. Beberapa pertanyaan diajukan oleh peserta kegiatan yang mengindikasikan sebelum kegiatan ini mereka cenderung mengabaikan dan tidak membaca label atau kode kemasan pangan yang mereka beli. Luaran dari kegiatan pengabdian masyarakat ini yakni pengetahuan berupa cara pembacaan label pangan dan kode kemasan.

\section{Pembahasan Hasil Kegiatan}

Tujuan dari kegiatan pengabdian masyarakat ini, yaitu memberikan edukasi label pangan dan kode kemasan. Hal ini dimaksudkan memberikan pemahaman dalam membaca label pangan dan kode kemasan. Tim pelaksana pengabdian masyarakat ini dilakukan oleh tiga orang dosen dari Universitas Indraprasta PGRI. Lokasi pelatihan ini dilakukan mushalla RW 03 Kecamatan Limo. Dipilihnya para anggota IKRA atas dasar beberapa pertimbangan setelah tim pengabdian masyarakat melakukan interviu/ wawancara dengan warga sekitar lokasi tersebut. Salah satu alasan yang paling mendasar adalah masih minimnya pemahaman tentang pembacaan label pangan dan kode kemasan.

Pada awal kunjungan tim pengabdian masyarakat kepada kedua mitra adalah membicarakan tujuan, bahan yang akan disampaikan, menentukan hari pembinaan yang ditentukan oleh kedua belah pihak. Pihak pertama yang diwakili oleh Ketua RT di RW 03 meminta adanya edukasi pemahaman tentang pembacaan label pangan dan kode kemasan.. Pihak kedua yaitu tim pengabdian masyarakat memberikan pelatihan dengan metode ceramah, diskusi, dan penugasan. Pelatihan tersebut dapat dilaksanakan dengan baik karena antusias dari para peserta untuk mengikuti pembinaan serta kerjasama yang baik antara kedua belah pihak. Berdasarkan hasil diskusi pada edukasi pemahaman tentang pembacaan label pangan dan kode kemasan maka diperoleh hasil sebagai berikut.

1. Peserta mendapat pemahaman tentang pembacaan label pangan

2. Peserta mendapat pemahaman tentang pembacaan kode kemasan.

3. Draft modul pedoman pembacaan label pangan dan kode kemasan

\section{SIMPULAN}

Kegiatan pengabdian masyarakat ini memberikan nilai positif, karena dapat memberikan materi yang bermanfaat kepada para anggota IKRA yang mayoritas dari mereka merupakan peserta didik dari Sekolah Menengah mengenai pentingnya membiasakan membaca label pangan serta kode kemasan pangan yang dibeli. Kebiasaan membaca ini sebagai suatu kesadaran akan pentingnya memahami informasi mengenai amannya komposisi maupun kemasan pangan. Selanjutnya, informasi yang sudah disampaikan dalam komunitas ini diharapkan bisa disebarluaskan ke khalayak sekitar sehingga tumbuhlah kebiasaan membaca label pangan dan kode kemasan.

Saran dalam pelaksanaan kegiatan abdimas ini adalah agar kegiatan ini dapat terus dilanjutkan dengan mitra abdimas lainnya. Selain itu, peran pemuda perlu ditingkatkan lagi karena peran pemuda sangatlah dibutuhkan sebagai pioneer perbaikan di lingkungannya. 


\section{DAFTAR PUSTAKA}

Ahmadi, F. (2010). Meningkatkan Minat Membaca Siswa Sekolah Dasar Dengan Metode Glenn Doman Berbasis Multimedia. Jurnal Penelitian Pendidikan, 27(1). Retrieved from http://journal.unnes.ac.id/nju/index.php/JPP/article/viewFile/194/202

Amna, P., Azwandi, Y., \& Yunus, M. (2013). Meningkatkan Kemampuan Membaca Pemahaman Pada Siswa Tunarungu Dengan Menggunakan Teknik Skimming. Jurnal Pendidikan Khusus, 2(3). Retrieved from http://ejournal.unp.ac.id/index.php/jupekhu/article/viewFile/2131/1795

Aulina, C. N. (2012). Pengaruh Permainan dan Penguasaan Kosakata Terhadap Kemampuan Membaca Permulaan Anak Usia 5-6 Tahun. PEDAGOGIA: Jurnal Pendidikan, 1(2), 131-144. Retrieved from http://ojs.umsida.ac.id/index.php/pedagogia/article/viewFile/36/42

Harras, K. A. (2014). Membaca 1. Retrieved from http://repository.ut.ac.id/4744/1/PBIN4108-M1.pdf

Hastuti, S. D. (2012). Upaya Peningkatan Kemampuan Membaca Pemahaman Melalui Metode Cooperative Integrated Reading And Composition Pada Siswa Kelas V Sdn I Manggung Ngemplak Boyolali Tahun Pelajaran 2012/2013. Universitas Muhammadiyah Surakrta. Retrieved from http://eprints.ums.ac.id/19998/21/NASKAH_PUBLIKASI.pdf

Indonesia, P. R. (2012). Undang-Undang Republik Indonesia Nomor 18 Tahun 2012 tentang Pangan. Jakarta (ID): Sekretariat Negara. Retrieved from http://codexindonesia.bsn.go.id/uploads/download/UU_Pangan_No.18_.pdf

Ngarbingan, A. A. (2016). Komunitas Dibo-dibo: studi tentang aktivitas sosio-ekonomi komunitas Dibo-dibo di Sahu Kabupaten Halmahera Barat. Magister Studi Pembangunan Program Pascasarjana UKSW. Retrieved from http://repository.uksw.edu/bitstream/123456789/9310/2/T2_092006104_BAB II.pdf

Permatasari, A. (2015). Membangun Kualitas Bangsa dengan Budaya Literasi. Retrieved from http://repository.unib.ac.id/11120/1/15-Ane Permatasari.pdf

Purwanta, M. A. (2012). Pelanggaran Hukum Perlindungan Konsumen Terhadap Penggunaan Produk Plastik berbahaya Sebagai Kemasan Makanan dan Minuman. Jurnal Hukum Dan Peradilan, 1(3), 487-511. Retrieved from http://www.jurnalhukumdanperadilan.org/index.php/jurnalhukumperadilan/articl e/download/136/147

Syahlani, S. P. (2006). Efek informasi, sumber komunikasi pemasaran dan label pangan dalam proses adopsi: studi perilaku adopsi pangan fungsional. Gadjah Mada 
University Yogyakarta. Retrieved from http://repository.wima.ac.id/6539/2/Bab 1.pdf

Tambunan, A. U. (2017). PERKEMBANGAN KOMUNITAS BASSKOMED DI KOTA MEDAN. UNIMED. Retrieved from http://digilib.unimed.ac.id/24834/4/09 NIM 2123140003 CHAPTER I.pdf 